\title{
A Study about Understanding the Concept of Force and Attitude towards Learning Physics on First-Year Students in the Course of General Physics; as Preliminary Investigation in Development Research
}

\author{
Fatni Mufit* \\ *Faculty of Mathematics and Science, State University of Padang \\ fatni.mufit@gmail.com
}

\begin{abstract}
The concepts of science, including physics should be understood by students, because science is supporting the advancement of technology. But most students assume that learning physics is difficult because it is associated with physics equations or formulas. Students also had difficulty in understanding the concepts of physics, and even common misconceptions. This study aims to investigate the students understanding of the concept of force and know the attitude of students towards learning physics. Samples or subjects in this study were 43 students of the first year of physics education who has taken the course of General Physics. The data collection of research done in two ways, namely test (quantitative) and questionnaire (qualitative). Instruments to collect data about the understanding of physics concept style is a standard test FCI (Force Concept Inventory), and supported by data from a questionnaire about the reasons for choosing an answer. Instruments to know the attitude of students towards learning physics is a standard questionnaire CLASS (Colorado Learning Attitude about Science Survey). Test data were analyzed using t-test and questionnaire data were analyzed descriptively. The results showed that the students understanding of the concept of force is very low ( $\leq 50 \%)$. The majority of college students have misconceptions about force, especially the force on the vertical motion, circular motion, parabolic/projectile motion and a simple pendulum motion. Based on the analysis of student attitudes, found that; the students find it difficult to resolve the problems of physics concepts although they have understood the topic in question. Students also felt that the equations of physics do not support their ideas in understanding concepts of physics equations required only for a matter of course. These findings are discussed, and made initial design of development research on learning materials.
\end{abstract}

Keywords: concept of force, misconception, attitude towards learning physics

\section{INTRODUCTION}

Problems in learning physics that often arises is the difficulty of learners in understanding physics concepts. Physics is considered as a difficult subject and less fun because it is loaded with equations or formulas that are not easy to understand. This fact is often revealed by the recognition of the learners during the learning of General Physics or Fundamental Physics. This is reinforced by the results of research Putra (2013), which found that in general, students still feel the physics of matter that are in the category difficult. Three factors make it difficult physics are (1) the factor that comes from self-regulation of individual students, (2) factors derived from the arrangement by the manager of learning physics and (3) factors are derived from the inherent properties of materials physics. Olusola, et.al, (2012) also states that physics is regarded as a 
difficult subject for students ranging from middle school to university and also by adults in graduate education.

In addition, the observation and experience of the author of the new students at the beginning of the term of General Physics, too much going on student misconceptions in understanding of physics concepts, such misconceptions on the concept of 'mass' and 'weight'. Many students who think the same concept of 'mass' and 'weight'. This happens because in the daily life of students, the term 'mass' and 'weight' is no different. Though the two concepts in physics are very much different. The author also found the misconceptions of physics at the physics teacher who underwent PLPG activities, through observation during the implementation of peer teaching, not a few teachers who showed misconceptions, including the concept of force in the application of Newton's Laws; that the gravity and the normal force are pairs of force action and reaction (Newton's third law), and there is no force acting on a stationary object (Newton's first law), or misconceptions another: Newton's first law only applies to stationary objects only, and so forth. Some research also suggests misconceptions of physics that occur in elementary school teacher (Baser 2006; pujayanto, 2011), a high school teacher and Madrasah Aliyah (Wahyudi, 2013; Holomoan, 2008), and the college student (Kabaca, et al, 2011; Saputri, 2012; Taufiq 2012; Suastika 2015; Saputri 2015). Researchers trying to uncover and identify the concepts of physics common misconceptions and apply specific learning strategies in an attempt to remediate these misconceptions.

Wandersee, Mintzes, and Novak, 1994 (in Suparno, 2013) states that misconceptions or alternative concepts occur in all areas of physics. Of the 700 studies on misconceptions, there are 300 who studied in the field of mechanics, 159 on electricity, 70 of thermal, optical and material properties, 35 of earth and space as well as 10 studies on modern physics. Misconceptions in the field of mechanics widely studied because it is the main starting materials and the high schools and as well as in the first years of college. Misconceptions of college student prospective teacher of will have an impact on the 'contagion' misconceptions to their students when they become teachers later.

The attitude of the students towards learning physics can also affect the performance of students in solving physics problems. Olusola, et al, (2012) found that the cause of the poor performance of students in learning physics is due to lack of information, lack of confidence, inability to solve problems in physics correctly using the appropriate formula, and unable to see the relevance of physics to everyday activities in society. Likewise, Kaya, et al, (2011) states that one of the factors that influence negatively students' attitudes toward learning physics is the study of physics held in the classroom based only on theory. Though the invention is much better to learn by associating concepts of physics to students' daily lives. Thus, the attitude of students towards learning physics of which is influenced by the presentation of learning by educators and learners are actively involved in the learning process.

This study aimed to investigate the understanding of physics concepts and misconceptions that occur in the first year students in college and know the attitude of the students towards learning physics. The research question in this study are: (1) How can understanding the concept of 'force' in the first year students who have taken the course of General Physics? (2) What 'force' concept 
into the misconceptions by the students? (3) What is the attitude of the students towards learning physics?

\section{THEORETICAL FRAMEWORK}

Some definitions misconception is described by experts, that misconception is defined as an interpretation of the concepts in an unacceptable statement (Novak, in Suparno, 2013). Meanwhile, Fowler (in Suparno, 2013) explains the misconceptions in more detail as the understanding is not accurate concept, the use of the wrong concept, classification examples wrong, chaos of different concepts, and the hierarchical relationship concepts that are not correct. In physics, misconceptions can be interpreted as the use of a physics concept that is incompatible with the concept described by experts or scientists of physics that have been scientifically acceptable.

Misconceptions or errors understand physics concepts, generally occurs when learners construct knowledge and understanding before following the learning process of physics formally in educational institutions, such as the concept of 'weight', 'heat' and 'effort', they've got the concept in daily activities, different with concepts in physics that they receive at the institution. The initial concept or preconceptions they bring sometimes at odds with the concept brought by experts or scientists. Error understand the concept of what is called misconceptions or alternative concepts.

Howard Gardner (in Carin, 1997) states that misconception or concepts naive survive because of early education teachers do not give students the chance to retest the misconception that obtained by the students at an early age. Misconceptions and naive theory may persist even after students successfully complete courses in a school. For example; of everyday students see that 'the rock falling faster than the the leaves'. If the students are not learning in school to experience things that are contrary to their naïve theory that, ie for example; leaves and stones fell together in vacuum space, the naive theory or misconceptions students will be resistant or stick to the higher education level.

\section{Attitudes Toward Learning Physics}

The term "attitude" is defined as an evaluation of positive or negative affect on people, objects, events, activities, or ideas in an environment of individuals that affect the way an individual was in response to an external stimulus (Zimbardo and Gerrig, 1999, in Arce, et al, 2014). Attitude is also associated with the management of emotions that occur during the learning process, and was instrumental in directing human behavior. Attitude is happening is part of a system of values and beliefs, whether positive or negative, the attitudes will affect the learning process directly and affect the future lives of individuals (Seferoglu 2004 ;. Sunbul et al, 2004; in Kaya, et al, 2011), The attitude of the students towards learning physics will affect the student's behavior in response to the stimulus in the learning process of physics. Educators need to know the attitude of students towards learning physics, foster a positive attitude and reduces the negative attitude to cultivate good learning behavior. 


\section{METHOD}

This study is a preliminary phase of development research learning materials. At this preliminary phase conducted survey research on understanding the concepts of physics and physics student attitudes toward learning to know more in-depth the problem of understanding the concepts and misconceptions students, and is the basis for the phase of design or prototype in the next. Plomp, et al, (2013) states that usually each research design can be used for realizing more than one research function, such as survey, case studies, experiments, and so forth.

The sample consisted of 43 students of physics education at the State University of Padang, which has been taking courses in General Physics. Data collection techniques using non-test techniques and tests. The research instrument consists of three types: (1) test FCI (Force Concept Inventory); is a standardized test consisting of 30 multiple-choice test items to investigate the students understanding of the basic concepts of force. FCI has been translated into 10 languages (including Indonesian) and has been used widely in the level of secondary schools and universities in various countries. Concepts in FCI includes material kinematics, Newton's first law, Newton's second law, Newton's third law, the resultant force, as well as other types of forces. (2) Test standard attitude CLASS (Colorado Science Learning Attitude Survey) to measure attitudes and beliefs of students, consisting of 42 statements about the attitude of students toward learning physics. Statements in CLASS is equipped with a 1-5 Likert scale ranging from Strongly Disagree (SDA) to Strongly Agree (SA), (3) Open quessionaire about the reasons for choosing an answer FCI, and the equations used; to know in depth understanding of the concepts and misconceptions students. Data analysis techniques menggunaakan t test, percentages and descriptivelly analysis.

\section{RESULT AND DISCUSSION}

There are three parts of the results of this study, namely (1) of the test FCI data is acquired understanding of the concepts of physics students about the style is very low $(\leq 50 \%)$ and the majority of students also had misconceptions. (2) The misconception concept of force occurs in a vertical motion, horizontal motion and circular motion. It is also revealed from the questionnaire answers students. Below are examples of student answers to the questions FCI and questionnaires about the reason of their answers.

Problem 1. Two metal balls are the same size but one weighs twice as much as the other. The balls are dropped from the roof of a single story building at the same instant of time. The time it takes the balls to reach the ground below will be:

(A) about half as long for the heavier ball as for the lighter one.

(B) about half as long for the lighter ball as for the heavier one.

(C) about the same for both balls.

(D) considerably less for the heavier ball, but not necessarily half as long.

(E) considerably less for the lighter ball, but not necessarily half as long. 


\begin{tabular}{|l|c|c|c|c|c|}
\hline $\begin{array}{l}\text { Recapitulation } \\
\text { Student } \\
\text { Answers }\end{array}$ & A & B & C & D & E \\
\cline { 2 - 6 } & $39 \%$ & $14 \%$ & $\mathbf{1 2 \%}$ & $33 \%$ & $2 \%$ \\
\hline
\end{tabular}

Only $12 \%$ of students answered correctly (C). Meanwhile, 39\% of students answered A and 33\% of students answered D. Answers A and D, be elected the students because it fits with intuition or their 'common sense'. This is a common misconception, both among high school students and college students in the case of vertical motion.

This is reinforced by student questionnaire answers about reason the student answers and equations they use. From 9 respondents, obtained to problem 1, 22\% of students (2 students) answered correctly. One person can not give a reason, this indicates that the student does not know the concept of (guess). While 78\% of students answered incorrectly, but on the grounds of their answers indicated their misconceptions. They answered based on intuition rather than on a true scientific concept. Students also can not associate the equations of physics to concepts that explain these equations. (See Figure 1.).

In accordance with Carin (1997) which states that the topic of science 'motion of objects', naive theory is: 'heavier objects fall faster than lighter objects'. While the scientific explanation: 'acceleration proportional to the force'. Theory naive or student misconceptions are not easily changed, except with meaningful learning through the process of conceptual change. In the process of conceptual change, students must recognize that their personal theories themselves are in conflict with the accepted scientific view. They need reassurance that their theories are themselves inadequate, incomplete, or inconsistent with the experimental evidence.

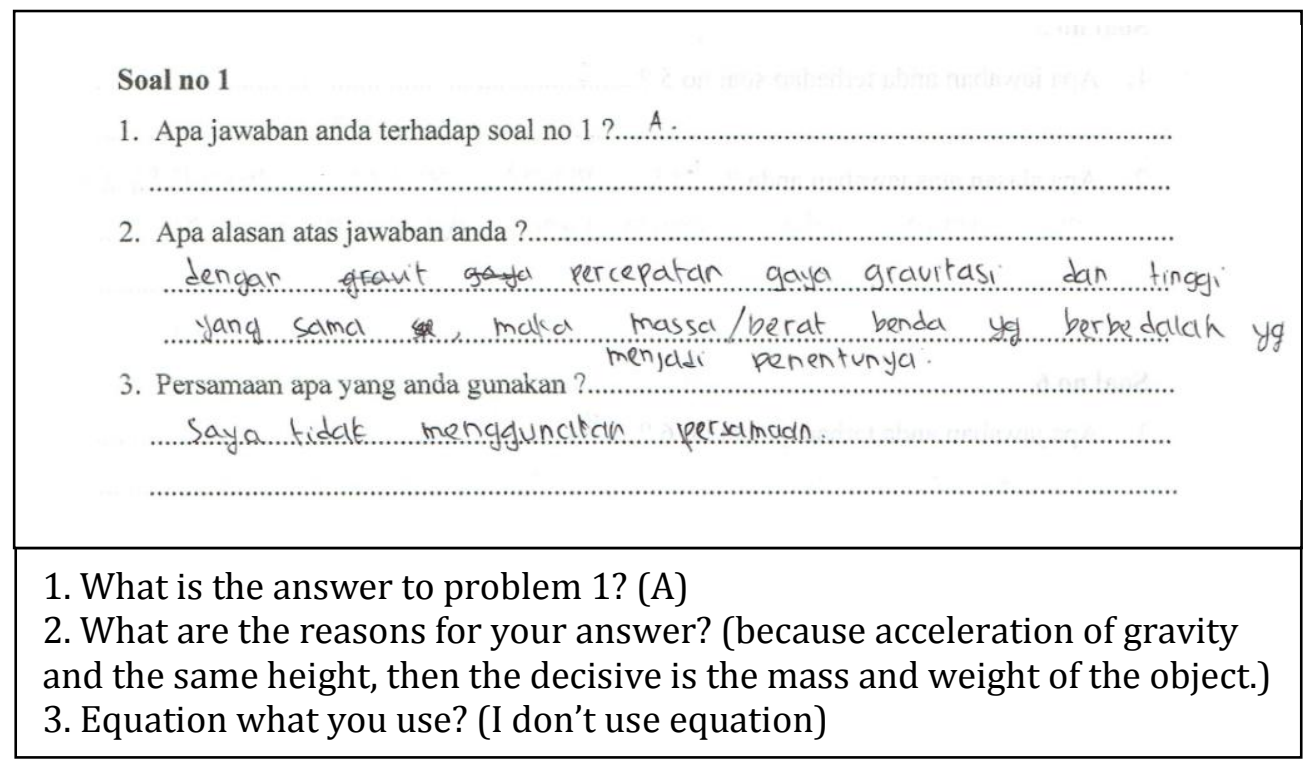

(a) 


\section{Soal no 1}

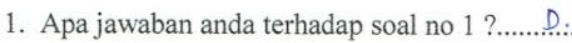

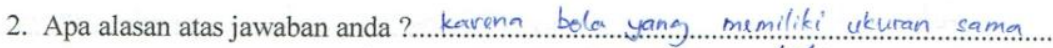
tetapi mempunyai berat yang beda maka boba yang memiliki berat yang besar lah yang sampai ketankh duluan, tapi trokk harus setengah

3. Persamaan apa yang anda gunakan ?. $v=\sqrt{2 g h}$

1. What is the answer to problem 1 ? (D)

2. What are the reasons for your answer? (because the balls are the same size but have different weight, then the ball has a great weight that hit the ground first, but not necessarily half) 3. Equation what you use? $(\mathrm{v}=\sqrt{2} \mathrm{gh})$

(b)

Figure 1. The reason the students answered (a) A and (b) D.

Both indicate a misconception

Below is the answer, and the reason for students to problem 14, which also showed a misconception.

Problem 14. A bowling ball accidentally falls out of the cargo bay of an airliner as it flies along in a horizontal direction. As observed by a person standing on the ground and viewing the plane as in the figure at right, which path would the bowling ball most closely follow after leaving the airplane?

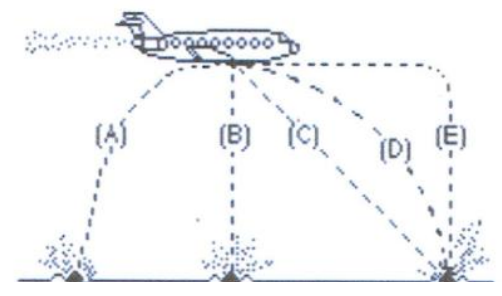

\begin{tabular}{|l|c|c|c|c|c|}
\hline $\begin{array}{l}\text { Recapitulation } \\
\text { Student } \\
\text { Answers }\end{array}$ & $\mathbf{A}$ & $\mathbf{B}$ & $\mathbf{C}$ & $\mathbf{D}$ & $\mathbf{E}$ \\
\cline { 2 - 6 } & $\mathbf{7 0} \%$ & $19 \%$ & $0 \%$ & $\mathbf{1 2 \%}$ & $0 \%$ \\
\hline
\end{tabular}

As many as $70 \%$ of students answered (A). The answer is the student intuition or 'common sense'. Only $12 \%$ of students answered correctly (D). No student answered (C) and (E) because the choice is unreasonable. Misconception look of the reasons the student answers, as shown in Figure 2. 
Soal no 14

1. Apa jawaban anda terhadap soal no 14 ?.....

2. Apa alasan atas jawaban anda ? kefike bola jatuh kec hta felt sanat

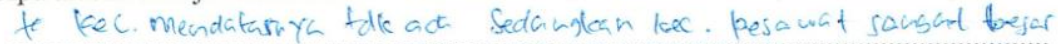

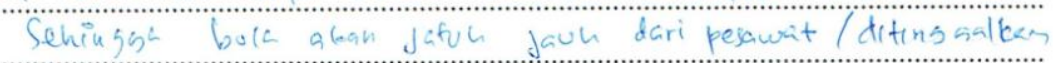
Pesawat

1. What is the answer to problem 14 ? (A)

2. What are the reasons for your answer? (When the bowling ball falls, no velocity horizontal direction. Meanwhile, the airplane speed is very large, so the bowling ball will fall away abandoned airplane.

(a)

Soal no 14

1. Apa jawaban anda terhadap soal no 14 ?....................

2. Apa alasan atas jawaban anda? Saat bola bowling yetuh dari capal terpang gy sedang melaju, mata bola acan jatuh bebas, pada saat jatuh permukaan bola bergesetan elg Udava, sehneg pada soat jatuh, bola tidale jatuh tepat di bawah pesawat, melainkan seditit te belakang

1. What is the answer to problem 14 ? (A)

2. What are the reasons for your answer? (when the bowling ball falling from a plane that was speeding, then the ball will be in free fall. At the time of tumbling, rubbing with air ball, so the ball does not fall right down, but slightly to the back.

(b)

Figure 2. Answer two students who show their misconception on the problem 14:

(a) the first student, (b) a second student

Based on analysis of 30 questions FCI, the students have problems in understanding the concept, including the problem of misconception, namely on the concept: (1) the force on the vertical motion, (2) force in circular motion, (3) the resultant force and the velocity vector, (4) force on a parabolic motion, (5) the force on the simple pendulum motion.

The results of the third part of this study were obtained from the survey of student attitudes toward learning physics (CLASS). The analysis showed that the attitude of students towards studying physics is still not good. Only $51 \%$ of students who had the pleasure of solving physics. As many as $81 \%$ find it difficult to resolve the problems of physics concepts although they have understood the topic in question in the matter. As many as $47 \%$ of students felt that the 
equations of physics do not support their ideas in understanding concepts of physics equations required only for a matter of course.

The results of this preliminary reseach used as a reference in designing learning materials based cognitive conflict in order to overcome various obstacles students in understanding the concepts of physics and remediate student misconceptions. Learning materials designed will give conflicting phenomenon in student thinking and guide students in finding the correct concept through physics equations related to the phenomenon. Students will be encouraged to think deeply find the correct concept in accordance with the scientific concept put forward by the experts. Learning materials is also designed to enable students and improve the performance of students in learning, particularly in finding concepts of physics are correct and remediate misconceptions physics students.

\section{CONCLUSION}

The students understanding of the concept of force is very low ( $\leq 50 \%)$. The majority of college students have misconceptions about force, especially the force on the vertical motion, circular motion, parabolic/projectile motion and a simple pendulum motion. Based on the analysis of student attitudes, found that; the students find it difficult to resolve the problems of physics concepts although they have understood the topic in question. Students also felt that the equations of physics do not support their ideas in understanding concepts of physics equations required only for a matter of course. Need designed cognitive conflict based learning materials to solve the problems of understanding of the concept and remediate misconceptions students, through a design or development research.

\section{REFERENCES}

Arce, J., Bodner, G.M., \& Hutchinson, K. (2014). A study of the impact of inquiry-based professional development experiences on the beliefs of intermediate science teachers about "best practices" for classroom teaching. International Journal of Education in Mathematics, Science and Technology, 2(2), 85-95. Retrieved from http://www.ijemst.net/article/view/ 5000036006

Baser, M. 2006. "Fostering conceptualchange by cognitive conflict based instruction on student understanding of heat and temperature concepts". Eurasia Journal of Mathematics, Science and Technology Education. 2(2). 96-114. Retrieved from http://www.ejmste.com/ 022006/ d6.pdf

Carin, Arthur A. (1997). Teaching Science Through Discovery, Eighth edition. Pearson Prentice Hall: New Jersey, Columbus Ohio.

Halomoan (2008). Analisis Konsepsi Guru Mata Pelajaran Fisika Madrasah Aliyah terhadap Konsep Gaya pada Benda Diam dan Bergerak. Retrieved from http://sumut.kemenag.go.id/,

Kabaca T, Z Karadag, M Aktumen (2011). Misconception, cognitive conflict and conceptual changes in geometry: a case study with pre-service teachers. Mevlana International Journal of Education (MIJE) Vol. 1(2), pp.44-55, 30 December, 2011. Retrieved from http://eujournal.org/index.php/esj/ article/download/3914/3705 
Kaya, H \& U.Boyuk (2011). Attitude Towards Physics Lessons And Physical Experiments Of The High School Students. European J of Physics Education Vol. 2 No. 1 ISSN 1309 7202. Retrieved from https://www.researchgate.net/publication/266031238_Attitudes_ Towards_Physics_ Lessons_and

Olusola, 00, Rotimi.CO. (2012) Attitudes of Students towards the Study of Physics in College of Education Ikere Ekiti, Ekiti State, Nigeria. American International Journal of Contemporary Research Vol. 2 No. 12; December 2012. Retrieved from http:// www.aijcrnet.com/ journals/Vol_2_No_12_December_2012/9.pdf

Plomp T, N Nieveen (2013). Educational Design Research, Part.A: An Introduction. SLO. Netherlands Institute for Curricullum Development. Retrieved from http://downloads. slo.nl/ Documenten/ educational-design-research-part-a.pdf.

Pujayanto (2011). Miskonsepsi IPA (Fisika) pada Guru SD. Jurnal Materi dan Pembelajaran Fisika (JMPF) Vol 1 No 1 (2011) 22-24. Retrieved from http://jurnal.fkip.uns.ac.id/ index. php/fisika/article / view/1856

Putra, Amali (2013). Persepsi Mahasiswa tentang Faktor-Faktor yang Menyebabkan Materi Fisika Sulit dan Bagaimana Cara Membuat Fisika Menjadi Lebih Mudah: Prosiding Seminar Nasional Pendidikan MIPA, 26 Oktober 2013 di Hotel Basko Padang. ISBN: 978-602-19877-1-1, hal 186-194, Universitas Negeri Padang.

Saputri D.F \& C Sarwanto (2012) Penyebab Dan Remediasi Miskonsepsi Gaya Menggunakan Multimedia Dan Modul. Jurnal materi dan pembelajaran fisika vol 2, 2012. ISSN: 2089-6158. Dapat ditemukan di

Saputri, D. F \& Nurussaniah. (2015) Penyebab Miskonsepsi Pada Optika Geometris. Prosiding Seminar Nasional Fisika (E-Journal) SNF2015, VOLUME IV, OKTOBER 2015. Retrieved from http://snf-unj.ac.id/kumpulan-prosiding/snf2015/

Suastika, T Jhoni, T Utami (2015). Penelusuran Miskonsepsi Mahasiswa Tentang Matriks Menggunakan Certainty of Response Index. Prosiding Seminar Nasional Fisika (E-Journal) SNF2015, Volume IV, Oktober 2015. Retrieved from http://snf-unj.ac.id/kumpulanprosiding/snf2015/

Suparno, Paul (2013). Miskonsepsi dan Perubahan Konsep dalam Pendidikan Fisika. PT. Gramedia Widiasarana Indonesia : Jakarta.

Taufiq, Muhammad (2012). Remediasi Miskonsepsi Mahasiswa Calon Guru Fisika Pada Konsep Gaya Melalui Penerapan Model Siklus Belajar (Learning Cycle) 5E. Jurnal Pendidikan IPA Indonesia JPII no I vol 2 pp. 198-203. Retrieved from http://journal. unnes.ac.id/ index.php

Wahyudi, I \& N Maharta ( 2013) Pemahaman Konsep Dan Miskonsepsi Fisika Pada Guru Fisika SMA RSBI Di Bandar Lampung. Jurnal Pendidikan MIPA, Volume 14, Nomor 1, April 2013. Retrieved from http://download.portalgaruda.org/ 